\title{
Tamalin Is a Critical Mediator of Electroconvulsive Shock-Induced Adult Neuroplasticity
}

\author{
Sudhirkumar U. Yanpallewar, Colleen A. Barrick, Mary Ellen Palko, Gianluca Fulgenzi, and Lino Tessarollo \\ Neural Development Section, Mouse Cancer Genetics Program, Center for Cancer Research, National Cancer Institute, Frederick, Maryland 21702
}

The molecular mechanisms underlying the effects of electroconvulsive shock (ECS) therapy, a fast-acting and very effective antidepressant therapy, are poorly understood. Changes related to neuroplasticity, including enhanced adult hippocampal neurogenesis and neuronal arborization, are believed to play an important role in mediating the effects of ECS. Here we show a dynamic upregulation of the scaffold protein tamalin, selectively in the hippocampus of animals subjected to ECS. Interestingly, this gene upregulation is functionally significant because tamalin deletion in mice abrogated ECS-induced neurogenesis in the adult mouse hippocampus. Furthermore, loss of tamalin blunts mossy fiber sprouting and dendritic arborization caused by ECS. These data suggest an essential role for tamalin in ECS-induced adult neuroplasticity and provide new insight into the pathways that are involved in mediating ECS effects.

\section{Introduction}

Electroconvulsive shock (ECS) is an effective and fast-acting therapy for patients with major depression. Unlike drug therapy, which requires several weeks to exert its effect, ECS can provide both immediate relief from depression, possibly by affecting immediate neurochemical alterations, and long-term effects by affecting neuroplasticity (Malberg et al., 2000). The changes in neuroplasticity include increased adult neurogenesis and neuronal sprouting in the hippocampus. ECS animal studies have shown that a wide variety of molecules, including neurotrophins, neurotransmitters, neuropeptides, and their receptors, undergo significant changes in expression (Altar et al., 2004). Other proteins, such as those with scaffolding activity, also show expression changes after ECS and are of particular interest because they are capable of affecting multiple pathways inducing both short-term and long-term changes. For example, homerla is significantly upregulated by ECS, and its injection into rats regulates neuronal excitability (Sakagami et al., 2005). Moreover, homerla affects both signal transduction as well as cytoskeletal rearrangements (Fagni et al., 2002). Despite the identification of genes whose expression changes during ECS, it is still unclear which molecules and pathways are essential for mediating its effects (Altar et al., 2004; Kato, 2009).

Tamalin is a scaffold protein that interacts with group 1 metabotropic receptors (mGluR1 and mGluR5), a truncated iso-

\footnotetext{
Received Oct. 31, 2011; revised Dec. 7, 2011; accepted Dec. 13, 2011.

Author contributions: S.U.Y., G.F., and L.T. designed research;S.U.Y., C.A.B., M.E.P., and G.F. performed research; S.U.Y., G.F., and L.T. analyzed data; S.U.Y. and L.T. wrote the paper.

This research was supported by the Intramural Research Program of the National Cancer Institute, Center for Cancer Research, National Institutes of Health. We thank Eileen Southon and Susan Reid for technical help in generating the tamalin mutant mouse model, Jodi Becker for technical help, and Dr. Mehdii Tufti for the homer1a construct.

Correspondence should be addressed to Lino Tessarollo, Neural Development Section, Mouse Cancer Genetics Program, Center for Cancer Research, National Cancer Institute, Building 560, Room 32-31D, Frederick, MD 21702. E-mail: tessarol@mail.nih.gov.

DOI:10.1523/JNEUROSCI.5493-11.2012

Copyright $\odot 2012$ the authors $\quad 0270-6474 / 12 / 322252-11 \$ 15.00 / 0$
}

form of the neurotrophin-3 receptor TrkC, and multiple postsynaptic and protein-trafficking scaffold proteins (Kitano et al., 2003; Hirose et al., 2004; Esteban et al., 2006). Tamalin mRNA expression is highest in brain areas, such as the hippocampus, that undergo significant structural plasticity. Although it is not required for normal brain development, tamalin deficiency in the mouse reduces morphine and cocaine sensitivity, probably by affecting the adaptive neural plasticity involved in reinforcement and addiction in drug abuse (Ogawa et al., 2007).

These results prompted us to investigate whether tamalin could influence adaptive neural plasticity occurring in other paradigms. In this study, we found a robust increase in tamalin expression in response to kainate and ECS. Moreover, in contrast to the increased hippocampal neurogenesis and neuronal sprouting observed in wild-type (WT) mice subjected to ECS, mice lacking tamalin had a blunted response. Thus, tamalin is dispensable for development but is required to mediate ECS-induced adult hippocampal neuroplasticity.

\section{Materials and Methods}

ECS. ECS was administered via bilateral ear clip electrodes using an Ugo Basile ECS unit (model 57800) (Vaidya et al., 1999). Animals received sham treatment or ECS (current, $18 \mathrm{~mA}$; shock duration, $0.5 \mathrm{~s}$; frequency, 100 pulses/s; and pulse width, $0.5 \mathrm{~ms}$ ) for 1,5 , or 10 consecutive days and were killed at specific time points depending on the analysis.

To evaluate the changes in tamalin mRNA expression, WT animals were subjected to sham or a single ECS treatment, and sacrificed at 1 , $3,6,12$ and $24 \mathrm{~h}$. For chronic treatment, a set of animals was subjected to ECS or sham treatment daily for 5 consecutive days and killed $24 \mathrm{~h}$ after the last treatment. Animals were perfused with $4 \%$ paraformaldehyde (PFA), after which their brains were removed and processed for in situ hybridization.

Kainate treatment. Adult mice were injected with kainate $(10 \mathrm{mg} / \mathrm{kg}$, i.p.; Sigma) or vehicle as described previously (Jiang et al., 2008). After $3 \mathrm{~h}$, they were killed and perfused with 4\% PFA. Coronal brain sections were then taken for in situ hybridization or immunohistochemistry analysis.

In situ hybridization. Digoxygenin (Dig) in situ hybridization protocols using the sense or antisense full-length tamalin (Esteban et al., 2006) 
and homerla (a gift from Dr. Mehdi Tafti, University of Lausanne, Lausanne, Switzerland) riboprobes were performed as follows. Dig-labeled RNA probes were synthesized by using the Promega Riboprobe system. Serial cryostat coronal sections $(50 \mu \mathrm{m})$ were proteinase K treated (5 $\mu \mathrm{g} / \mathrm{ml})$ in PBS and postfixed in $4 \%$ PFA. Sections were then incubated in hybridization buffer ( $50 \%$ formamide, $5 \times$ SSC, $50 \mu \mathrm{g} / \mathrm{ml}$ yeast tRNA, 50 $\mu \mathrm{g} / \mathrm{ml}$ heparin, and $0.1 \%$ Tween 20$)$ for $1 \mathrm{~h}$ at $70^{\circ} \mathrm{C}$ and then hybridized with the specific probes overnight at $70^{\circ} \mathrm{C}$ in the same buffer. Unbound probes were removed by several posthybridization washes [two washes of $30 \mathrm{~min}$ in $50 \%$ formamide, $5 \times \mathrm{SSC}$ at $70^{\circ} \mathrm{C}$, followed by two washes of 30 min each in Tris buffer $(0.1 \mathrm{M}$ Tris- $\mathrm{HCl}, 0.5 \mathrm{M} \mathrm{NaCl}$, and $0.1 \%$ Tween 20$)$ at room temperature (RT) and two washes of $30 \mathrm{~min}$ in $50 \%$ formamide, $2 \times \mathrm{SSC}$ at $\left.70^{\circ} \mathrm{C}\right]$. After blocking for $1.5 \mathrm{~h}$ at RT in blocking solution $[10 \%$ normal goat serum (NGS) and $2 \mathrm{~mm}$ levamisole], sections were incubated overnight at $4^{\circ} \mathrm{C}$ with alkaline phosphatase-conjugated anti-Dig antibodies (1:2000; Roche) diluted in TBST containing 1\% NGS and 2 mu levamisole. After six washes of $30 \mathrm{~min}$ in TBST, sections were incubated for two times for $10 \mathrm{~min}$ in NTMT (100 mM NaCl, $100 \mathrm{~mm}$ Tris$\mathrm{HCl}$, pH 9.5, $50 \mathrm{~mm} \mathrm{MgCl}_{2}$, and 0.1\% Tween 20) and then in NBT/BCIP substrate (Roche) at RT to develop the signal. After overnight air drying, slides were then coverslipped with DPX mounting media.

Generation of tamalin knock-out mice. The ATG-containing exon of the tamalin gene was targeted in mouse embryonic stem (ES) cells by a standard replacement-type targeting vector constructed by microhomologous recombination in bacteria using a 129/SV mouse genomic fragment (Tessarollo et al., 2009). Electroporation and selection were performed using the CJ7 ES cell line as described previously (Southon and Tessarollo, 2009). DNAs derived from G418/FIAU-resistant ES clones were screened by a diagnostic BamHI restriction enzyme digestion using a $3^{\prime}$ probe external to the targeting vector sequence. Recombinant clones containing the predicted rearranged band were obtained at a frequency of one in four. Two independently targeted ES cell clones injected into C57BL/ 6 blastocysts generated chimeras that transmitted the mutated allele to the progeny (Reid and Tessarollo, 2009). After germ-line transmission of the targeted ES cell clones, the diagnostic BamHI digest was used for screening because it enabled us to distinguish between the WT and all the targeted alleles, including those generated after cre or Flpe recombination.

Mutant mice were backcrossed for at least 10 generations onto the C57BL/6 background before use. Animals of either sex were used for experimentation. Mice were bred in a specific, pathogen-free facility with food and water ad libitum. All experimental procedures followed the National Institutes of Health guidelines for animal care and use and were approved by the National Cancer Institute-Frederick Animal Care and Use Committee.

Behavioral analysis. For a general behavioral characterization, mice were subjected to the elevated plus maze as a measure of locomotor activity (number of crosses) and anxiety-related behavior (time spent in an open arm) (Zhang et al., 2011), the rotarod test (time spent on a rotating rod) to evaluate muscle strength and motor coordination (Wang et al., 2007), and the forced swim test (immobility time) to detect possible depressive behavior phenotypes (Zhang et al., 2011).

BrdU injection protocol. For basal cell proliferation studies, animals were injected with BrdU (200 mg/kg, i.p.; Sigma) and killed 2 h later. For basal cell survival studies, animals were injected with BrdU $(200 \mathrm{mg} / \mathrm{kg}$, i.p.) once daily for 3 consecutive days and killed $28 \mathrm{~d}$ after the last BrdU injection (Yanpallewar et al., 2010). For analysis of ECS-induced proliferation of adult hippocampal progenitors, WT and tamalin knock-out (TKO) animals were subjected to ECS or sham treatment. Three days after ECS, they were injected with BrdU (200 mg/kg, i.p.) and perfused with 4\% PFA $2 \mathrm{~h}$ later (Ma et al., 2009). For analysis of ECS-induced adult neurogenesis, animals were subjected to single ECS or sham treatment; $3 \mathrm{~d}$ later, they were injected twice with $\operatorname{BrdU}(200 \mathrm{mg} / \mathrm{kg}$, i.p.) $12 \mathrm{~h}$ apart and killed $28 \mathrm{~d}$ after the last BrdU injection (Madsen et al., 2000).

Immunohistochemistry and immunofluorescence. Brains perfused with $4 \%$ PFA were serially sectioned (50 $\mu \mathrm{m}$ coronal cryostat sections), through the rostrocaudal extent of the hippocampus (bregma, -1.34 to $-2.80 \mathrm{~mm}$; Paxinos and Franklin, 2001). One in every fifth section was collected for BrdU, proliferating cell nuclear antigen (PCNA), or dou- blecortin (DCX) immunohistochemistry (six sections per animal) as described previously (Yanpallewar et al., 2010). The primary antibodies were rat anti-BrdU antibody (1:500; Accurate Biochemicals), rabbit antiPCNA (1:250; Santa Cruz Biotechnology), and goat anti-DCX antibody (1:500; Santa Cruz Biotechnology). The secondary antibodies were biotinylated goat anti-rat or goat anti-rabbit (1:500; Vector Laboratories) and biotinylated rabbit anti-goat (1:500; Vector Laboratories). Signal amplification was performed using a Vectastain Elite Avidin-Biotin (Vector Laboratories) and visualization was done using diaminobenzidine (Sigma) as substrate. Quantification of the number of BrdUpositive $\left(\mathrm{BrdU}^{+}\right), \mathrm{PCNA}^{+}$, and $\mathrm{DCX}^{+}$cells in tissue sections was performed using an unbiased stereology protocol as described previously (Ma et al., 2009; Yanpallewar et al., 2010).

Double-labeled immunofluorescence staining was used to determine the colocalization of the BrdU signal with the mature neuronal marker NeuN (Madsen et al., 2000). Sections subjected to antigen retrieval were incubated with both rat anti-BrdU (1:500; Accurate Biochemicals) and mouse anti-NeuN (1:500; Millipore) antibodies overnight at RT. The secondary antibodies Alexa Fluor 488 goat anti-mouse (1:500; Invitrogen) and Alexa Fluor 568 goat anti-rat (1:500; Invitrogen) were also used in combination for $2 \mathrm{~h}$. To address the effect of ECS on neurogenesis, the absolute number of $\mathrm{BrdU}^{+}$cells that also express NeuN was determined by confocal microscopy. All $\mathrm{BrdU}^{+} / \mathrm{NeuN}^{+}$cells (every fifth section, six sections in total per animal) were analyzed using $z$-plane confocal microscopy with $1 \mu \mathrm{m}$ steps (Carl Zeiss LSM510 confocal microscope).

Timm staining. Analysis of mossy fiber sprouting was done by using Timm staining as described previously (Vaidya et al., 1999). Animals received ECS or sham treatment for 10 consecutive days. Twelve days after the last treatment, they were perfused with $0.37 \%$ sodium sulfide (Sigma) followed by $4 \%$ PFA. After overnight fixation in 4\% PFA and cryoprotection with $30 \%$ sucrose, serial coronal sections $(50 \mu \mathrm{m})$ were cut on a cryostat through the rostrocaudal extent (bregma -1.34 to $-2.80 \mathrm{~mm}$; Paxinos and Franklin, 2001) of the hippocampus. One in every fifth section (six sections in total) was mounted on a slide, dried overnight, and developed in the dark in a 12:6:2 mixture of gum arabic, hydroquinone, and citrate buffer with $17 \%$ silver nitrate (Sigma). The intensity of Timm granules in the supragranular region of the hippocampal dentate gyrus (DG) was scored as follows (Vaidya et al., 1999): 0, no granules between the tip and the crest of the DG; 1, few granules with patchy distribution; 2, numerous granules with continuous distribution; 3 , prominent granules in a continuous pattern with occasional patches of confluence; 4 , prominent granules forming a laminar band; 5 , a confluent dense laminar band of granules that extends into the inner molecular layer.

Golgi-Cox impregnation and Golgi tracing. Brains from animals killed $12 \mathrm{~d}$ after treatment were removed from the skull and immersed in Golgi-Cox solution (combination of potassium dichromate, $\mathrm{HgCl}_{2}$, and potassium chromate, $\mathrm{pH}$ 6.3-6.4; Sigma) in a glass bottle for $7 \mathrm{~d}$ at RT in the dark and then transferred to $30 \%$ sucrose until additional processing. After at least $2 \mathrm{~d}$ in sucrose solution, coronal brain sections were serially cut at $\mathrm{RT}$ on a vibratome (125 $\mu \mathrm{m}$ coronal sections) through the rostrocaudal extent of hippocampus (bregma -1.46 to $-3.40 \mathrm{~mm}$; Paxinos and Franklin, 2011). Sections from a single animal were collected in a well of a six-well plate containing 30\% sucrose and mounted randomly (not sequentially) onto slides with $3 \%$ gelatin. Once on the slides, sections were brushed with $50 \%$ sucrose and allowed to air dry for $48 \mathrm{~h}$. They were then immersed in distilled water three times for $5 \mathrm{~min}$ with gentle shaking, transferred to a $4 \% \mathrm{KOH}$ solution for 5-10 min, and again rinsed in distilled water. After dehydration through graded ethanols, the slides were cleared with Histoclear (three times for $5 \mathrm{~min}$ ) and coverslipped with DPX mounting medium (Carim-Todd et al., 2009). To ensure random sampling, floating sections (12-14 per animal) were first collected in $30 \%$ sucrose and randomly mounted onto slides as described above. For tracing analysis, we started with the first section on the slide, and individual DG neurons that fulfilled the following selection criteria were included in the analysis. Neurons included in the analysis were chosen regardless of rostrocaudal level or the number of the section on the slide. DG neurons selected for analysis of dendritic arborization of the primary dendrite had to fulfill the following criteria: (1) isolated cell body with a 
clear relationship of the primary dendrite to the soma; (2) presence of untruncated dendrites and dark impregnation along the extent of all of the dendrites; and (3) relative isolation from neighboring impregnated cells that could interfere with the analysis. For each brain, 15 DG neurons were traced in 3D at $40 \times$ magnification using the Neurolucida software (MicroBrightField). The morphological traits of the cells (dendritic branching and length) were measured in successive radial segments of 20 $\mu \mathrm{m}$ using the center of the soma as a reference point (Sholl analysis). Sholl analysis was performed using Neuroexplorer (MicroBrightField) (Carim-Todd et al., 2009).

Western blot analysis. Brains were quickly removed and dissected, and the resulting tissue samples were immediately frozen in dry ice. After homogenization in NP-40 lysis buffer, supernatants were collected, mixed with Laemli's sample buffer $\left(2 \times\right.$; Sigma), boiled at $100^{\circ} \mathrm{C}$ for $5 \mathrm{~min}$, and subjected to SDS-PAGE. After separation by electrophoresis, proteins were transferred to PVDF membranes by electroblotting. Membranes were blocked in 5\% milk in TBST and incubated with a rabbit anti-tamalin (1:1000; Rockland) or $\beta$-actin (1:1000; Santa Cruz Biotechnology) specific antibody overnight at $4^{\circ} \mathrm{C}$. After washing, membranes were incubated with a donkey anti-rabbit HRP secondary antibody (1: 2500; Millipore), washed again, and exposed to Hyperfilm or to a Syngene Bio-Imaging System using the ECL detecting reagent (GE Healthcare). Band intensity quantification was done using either Gene Snap Software (Syngene Bio-Imaging) or ImageQuant Software (GE Healthcare).

Electrophysiological recording. Electrophysiological recording was performed $5 \mathrm{~h}$ after a single ECS. Three hours after treatment, mice under isoflurane anesthesia were decapitated, and their brains were removed. Transverse hippocampal slices (350 $\mu \mathrm{m}$ thick) were obtained with a vibroslicer (Leica) in ice-cold artificial CSF (ACSF) containing the following (in $\mathrm{mm}$ ): $125 \mathrm{NaCl}, 1.25 \mathrm{KCl}, 1 \mathrm{CaCl}_{2}, 1.5$ $\mathrm{MgCl}_{2}, 1.25 \mathrm{KH}_{2} \mathrm{PO}_{4}, 25 \mathrm{NaHCO}_{3}$, and 16 glucose, $\mathrm{pH}$ 7.4. Slices were incubated for $1 \mathrm{~h}$ at $32^{\circ} \mathrm{C}$ in a surface chamber filled with ACSF in which $\mathrm{CaCl}_{2}$ was raised to $2.5 \mathrm{~mm}$, and a gas mixture $\left(95 \% \mathrm{O}_{2}, 5 \% \mathrm{CO}_{2}\right)$ was continuously bubbled. After the first hour, temperature was reduced to $28^{\circ} \mathrm{C}$, and slices were kept in the same chamber until the transfer to the recording chamber. Slices were perfused with ACSF at $28^{\circ} \mathrm{C}$ at the rate of $2 \mathrm{ml} / \mathrm{min}$. Field EPSP (fEPSPs) were evoked in the molecular layer by stimulating the medial perforant path in the DG with a Teflon-coated concentric platinumiridium electrode and recorded with a borosilicate glass pipette (Sutter P90; Sutter Instruments) to obtain $4 \mathrm{M} \Omega$ tip resistance when filled with ACSF. An input-output curve was obtained by gradually increasing the stimulus intensity until the fEPSP reached a plateau. After that, the stimulus was reduced to obtain an fEPSP that was $50 \%$ of the maximum level. Baseline recording was obtained by stimulating the slice every $20 \mathrm{~s}$ for at least $45 \mathrm{~min}$. Once the baseline was stabilized to obtain LTP, three times for $1 \mathrm{~s}, 100 \mathrm{~Hz}$ trains every $20 \mathrm{~s}$ were delivered to the stimulating electrode. Baseline recording was then resumed and followed for $1 \mathrm{~h}$. Field potential was recorded (Multiclamp 700b; Axon Instruments), digitized (10 kHz Digidata 1324), low-pass filtered ( $3 \mathrm{kHz}$, eight-pole Bessel), and stored (Clampex 9.2; Axon Instruments). Signals were analyzed off line (Clampfit 9.2; Axon Instruments), and the size of the fEPSP was evaluated by measuring the initial slope of the signal expressed as percentage of the variation from the baseline value (average of $5 \mathrm{~min}$ before the conditioning protocol). Results were further analyzed with IGOR pro 6.01 (WaveMetrics). All data are reported as means \pm SE.

Statistical analysis. Data were analyzed using the Statistical Software GraphPad InStat and Prism. Data from two groups were analyzed using unpaired Student's $t$ test, whereas results from more than two groups were subjected to statistical analysis by two-way (multivariate) ANOVA followed by post hoc Bonferroni's test for group comparison. Two-way ANOVA was used to assess interaction between two factors, namely ECS treatment and genotype. For the Timm staining analysis, we used a nonparametric statistical test, ANOVA followed by post hoc Dunn test, because the data are presented as scores. For Sholl analysis of dendritic length and intersections, we used repeated-measures ANOVA, followed by post hoc Bonferroni's test for group comparison. A $p$ value $<0.05$ was considered statistically significant. 

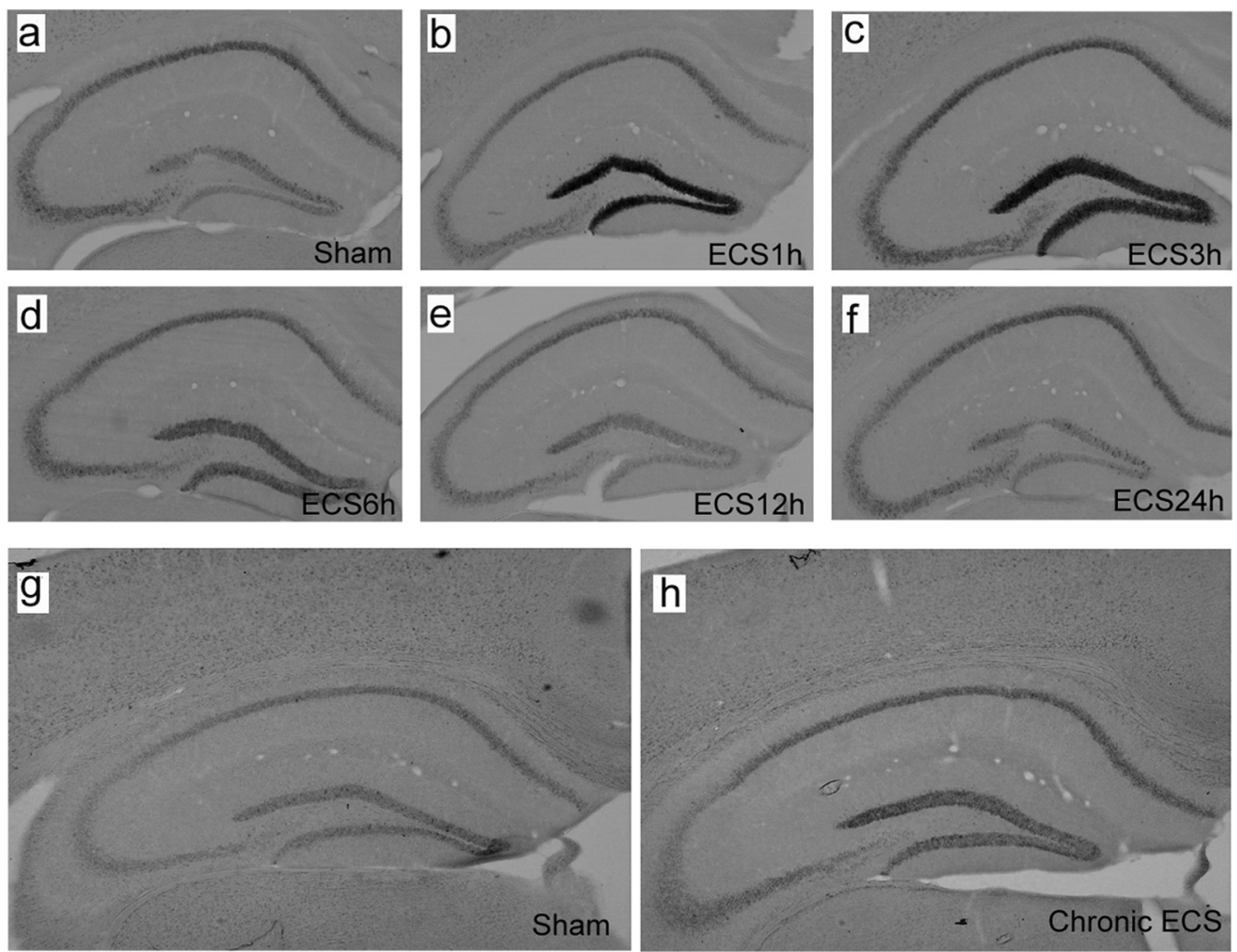

i

Control

ECS
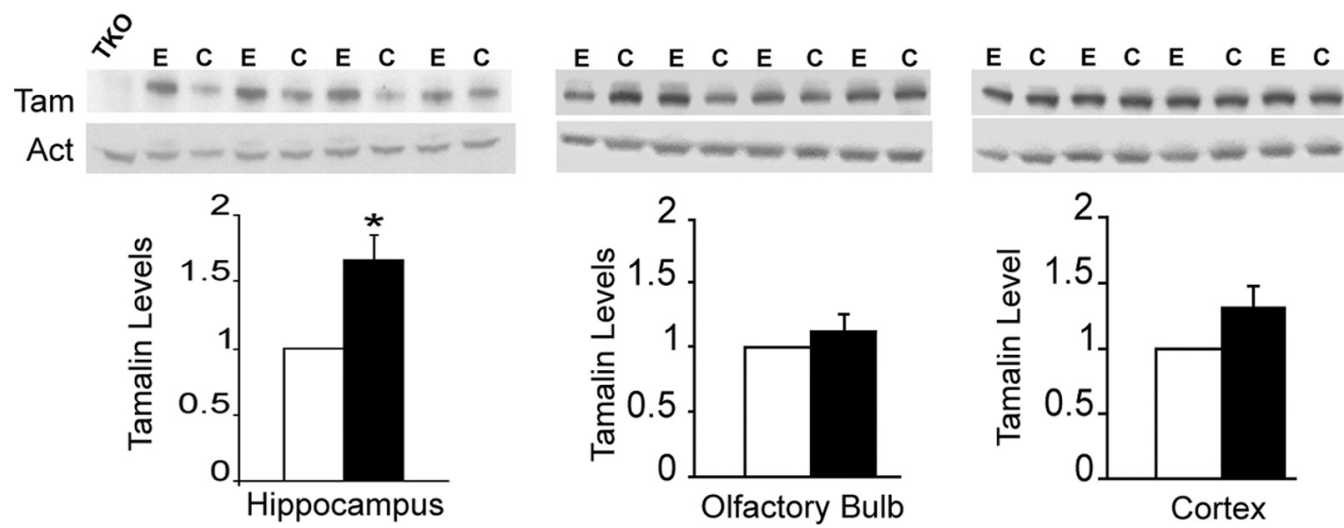

Figure 2. Hippocampal tamalin mRNA and protein are upregulated in response to ECS. Representative tamalin in situ hybridization analysis of hippocampus from mice after single (a-f) or chronic $(\boldsymbol{g}, \boldsymbol{h})$ ECS. Sham-treated animals show the basal level of tamalin expression $(\boldsymbol{a}, \boldsymbol{g})$. Tamalin mRNA is upregulated at $1 \mathrm{~h}(\boldsymbol{b})$ and peaks at $3 \mathrm{~h}(\boldsymbol{c})$ from ECS. Beginning at $6 \mathrm{~h}(\boldsymbol{d})$, tamalin is downregulated and returns to the pre-ECS level by $12(\boldsymbol{e})$ and $24 \mathrm{~h}(\boldsymbol{f})$. Note that tamalin mRNA expression remains upregulated at $24 \mathrm{~h}$ after chronic ECS $(\boldsymbol{h})$ compared with sham-treated controls $(\boldsymbol{g}) . n=4$ for each group. Expression of tamalin protein after chronic ECS (i). Animals received one ECS per day for 5 consecutive days and were killed $24 \mathrm{~h}$ after the last treatment. Western blot analysis of hippocampus (left), olfactory bulb (middle), and cortex (right) from ECS-treated (E) or sham-treated (C) WT animals using an anti-tamalin antibody (Tam); $\beta$-actin was used as loading control (Act), and a hippocampus lysate from a TKO mouse was used as negative control (TKO). The quantification of tamalin protein levels is shown at the bottom. Note the selective tamalin upregulation in the hippocampus. $n=4$ animal. $p<0.05$ by Student's $t$ test.

\section{Results}

\section{Tamalin is upregulated in the DG in response to kainate and ECS}

Because tamalin affects the adaptive neural plasticity involved in reinforcement of drug abuse (Ogawa et al., 2007), we decided to investigate whether it could influence adaptive neural plasticity events occurring in other paradigms.

We first characterized tamalin expression in response to neuronal excitation in the adult mouse hippocampus. We injected kainate (10 mg/kg, i.p.), an analog of glutamic acid, because it has been shown to increase the activity of dentate granule cells in the hippocampus (Zagulska-Szymczak et al., 2001) (Fig. 1). In accordance with previous reports, we found hippocampal upregulation of the immediate early genes arc (activity-related cytoskeletal protein), a classic activity-induced gene (Fig. 1e,f), and homerla, a scaffold protein that, like tamalin, has a PDZ domain (Fig. 1c,d). Next, we evaluated whether tamalin expression was affected by kainate treatment. In situ hybridization analysis showed that tamalin is also upregulated in the DG of the hippocampus in response to kainate treatment, suggesting that tamalin mRNA levels are increased under conditions of enhanced excitatory neurotransmission (Fig. 1a,b). To investigate whether tamalin 
expression was affected in another paradigm of enhanced neurotransmission, we tested its expression after ECS, a treatment used in patients with major depression. As reported previously, animals given a single ECS show a significant upregulation of arc in the DG (Fig. $1 i, j$; Valentine et al., 2000). Interestingly, we found that hippocampal tamalin expression also increases after ECS compared with sham-treated animals (Fig. 1g,h). Again, these data suggest that tamalin upregulation may play a role in conditions of enhanced excitatory neurotransmission.

Next, to characterize the temporal changes of tamalin expression in response to ECS, we subjected WT mice to single ECS and evaluated tamalin mRNA levels at different time points (Fig. 2). Specifically, the tamalin mRNA level begins to increase at $1 \mathrm{~h}$ and peaks by $3 \mathrm{~h}$ after ECS before returning to control levels by $12 \mathrm{~h}$ (Fig. 2a-f). Contrary to the transient increase produced by a single ECS, chronic ECS causes a longer-lasting increase in tamalin that persisted at least up to $24 \mathrm{~h}$ after the last ECS treatment (Fig. $2 g, h$ ). Interestingly, ECS causes not only an upregulation in hippocampal tamalin mRNA but also in its protein level. In fact, chronic ECS leads to a robust $67 \%$ elevation in tamalin protein level ( $p<0.05$; Fig. $2 i$, left). Moreover, tamalin upregulation is specific to the hippocampus because there is no significant change in the olfactory bulb or cortex, two other brain regions that also express tamalin (Fig. $2 i$, middle and right). Together, these data identify tamalin as a novel molecule showing dynamic changes in response to enhanced excitatory neurotransmission.

\section{Tamalin is essential for the ECS-induced proliferation of hippocampal progenitors}

Because of the clinical relevance of ECS for the treatment of chronic depression, we decided to evaluate whether tamalin mediates events related to ECS-induced adult neuroplasticity. We focused on the DG of the hippocampus, one of the regions in the adult brain that retains the ability to generate new neurons in response to a variety of stimuli including ECS (Madsen et al., 2000; Cameron and McKay, 2001).

To this end, we generated a tamalin KO (TKO) mouse model (Fig. 3). Tamalin deletion in the mouse does not cause any overt phenotype as also reported previously (Ogawa et al., 2007). Mutant mice are fertile, develop normally, have normal lifespan, and are indistinguishable from
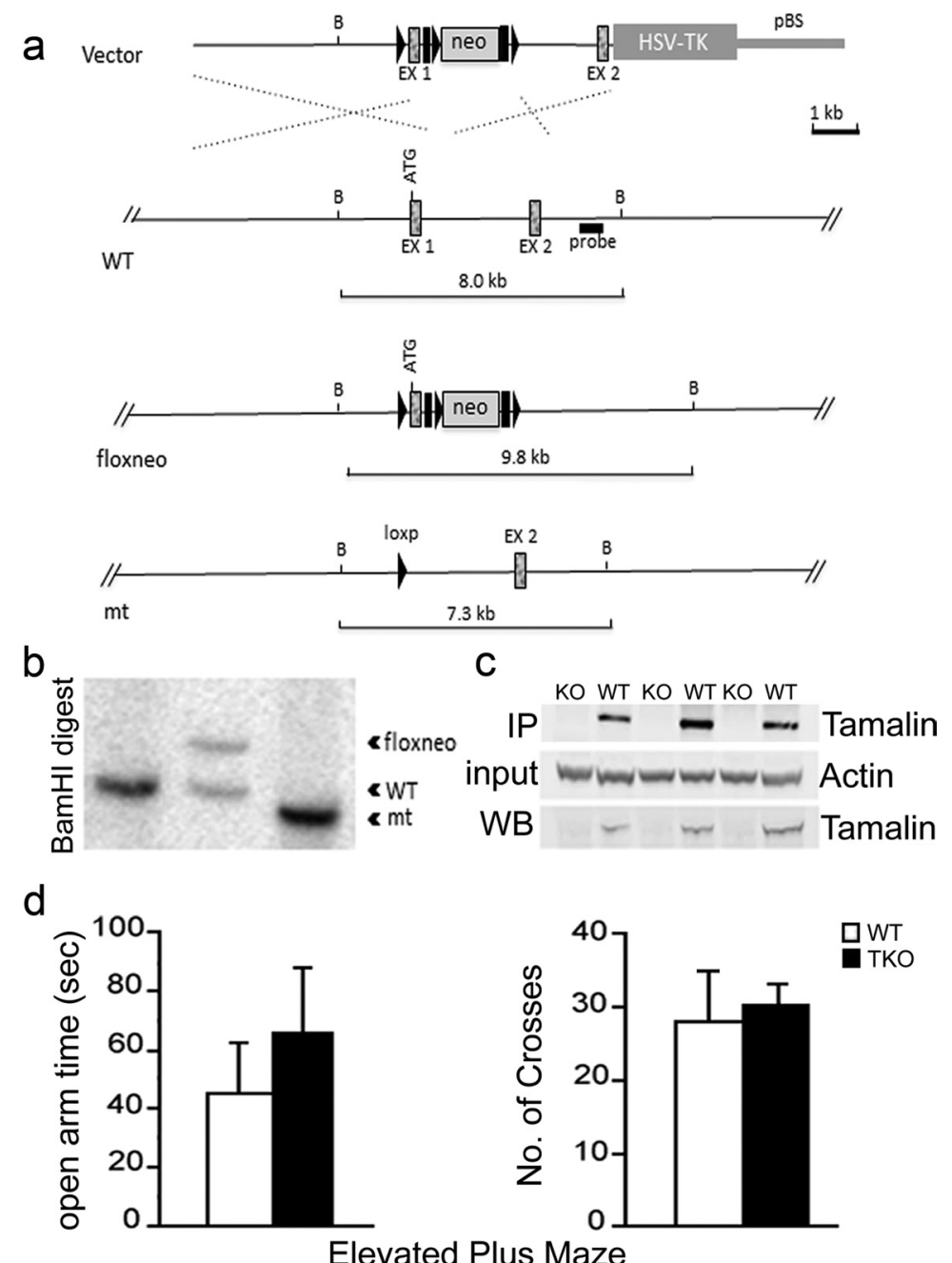

Elevated Plus Maze
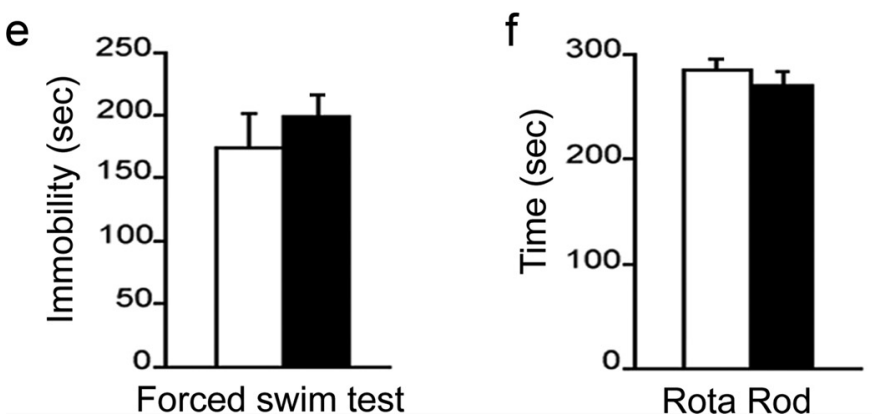

Figure 3. Targeted deletion of tamalin in mouse. Schematic representation of the strategy used to target the tamalin gene. LoxP sites (black triangles) were inserted upstream and downstream of the ATG-containing exon 1 (EX1). The neomycin resistance cassette (neo) is flanked by both loxP and Frt (black rectangles) sites. After the initial screening of the positive ES cell clones, as described in Material and Methods, a probe (black rectangle) downstream of EX1 was used for the identification of the different targeted alleles by detecting a shift from the endogenous BamHI WT band of $8 \mathrm{~kb}$ to the rearranged $9.8 \mathrm{~kb}$ band resulting from the insertion of the neo cassette by homologous recombination. Cre-induced excise of the tamalin-specific exon and the neo cassette causes a shift of the $9.8 \mathrm{~kb}$ band to $7.3 \mathrm{~kb}$. $\boldsymbol{b}$, Southern blot analysis of genomic DNA from mice with the tamalin alleles indicated in $\boldsymbol{a}$. Analysis of DNA digested with the BamHI restriction enzyme and probed with the $3^{\prime}$ fragment described in $\boldsymbol{a}$ yields the expected $8 \mathrm{~kb}$ band in a WT mouse (lanes 1) and a rearranged $9.8 \mathrm{~kb}$ fragment with the neo insertion (floxneo) in an heterozygous mouse and a $7.3 \mathrm{~kb}$ band in the mutant (lanes 2 and 3, respectively). c, Western blot analysis of hippocampus dissected from mutant (KO) or WT mice and hybridized with an antiserum directed against tamalin. The top panel is a Western blot analysis of lysates subjected first to immunoprecipitation (IP) with a tamalinspecific antibody and then to the blotting with the same antibody. The bottom panel is the Western blot analysis of straight hippocampus lysates hybridized with the tamalin-specific antibody. The middle blot was hybridized with an anti- $\beta$-actinspecific antibody to control for loading. Behavioral analysis of tamalin-deficient mice $(\boldsymbol{d}-\boldsymbol{f})$. Animals were subjected to the elevated plus maze $(\boldsymbol{d})$, forced swim $(\boldsymbol{e})$, and rotarod $(\boldsymbol{f})$ test. $n \geq 7$. 

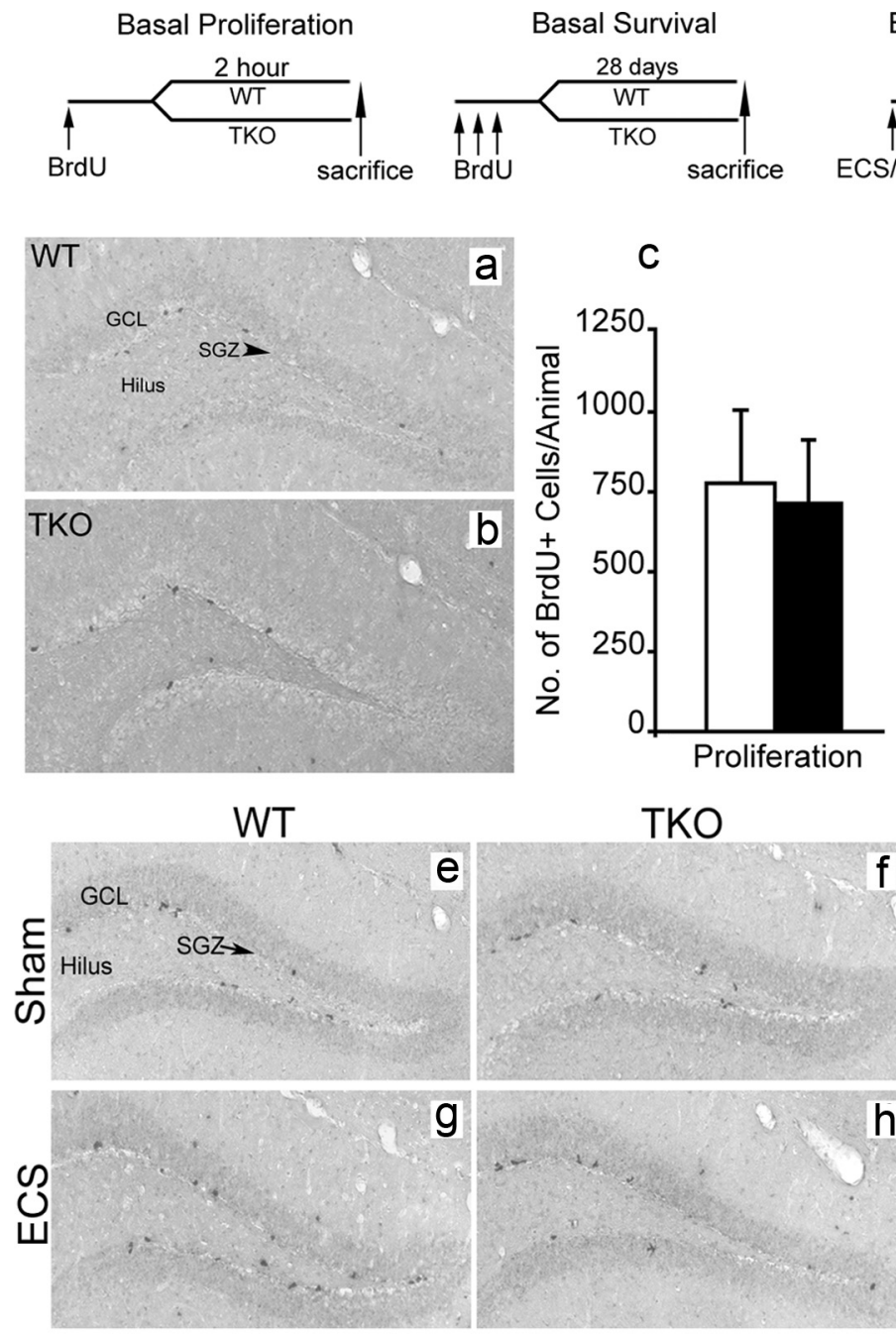

TKO

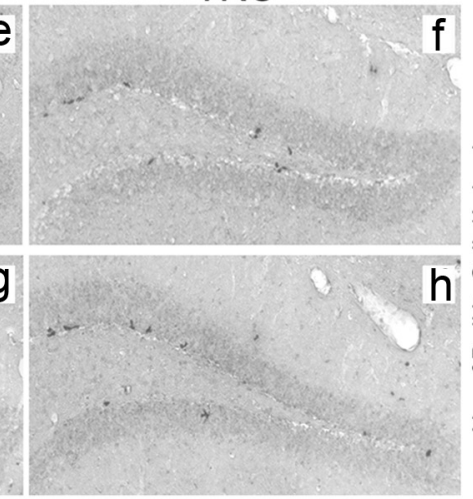

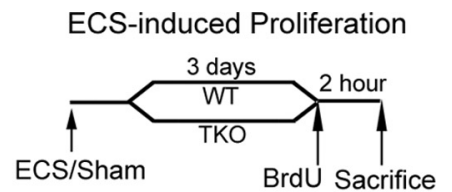

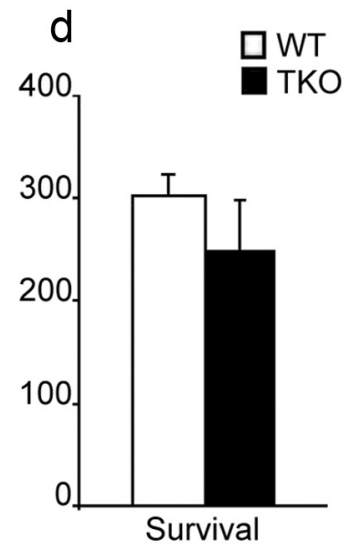

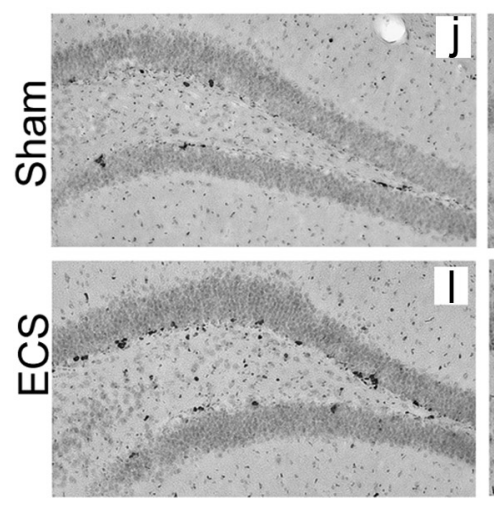
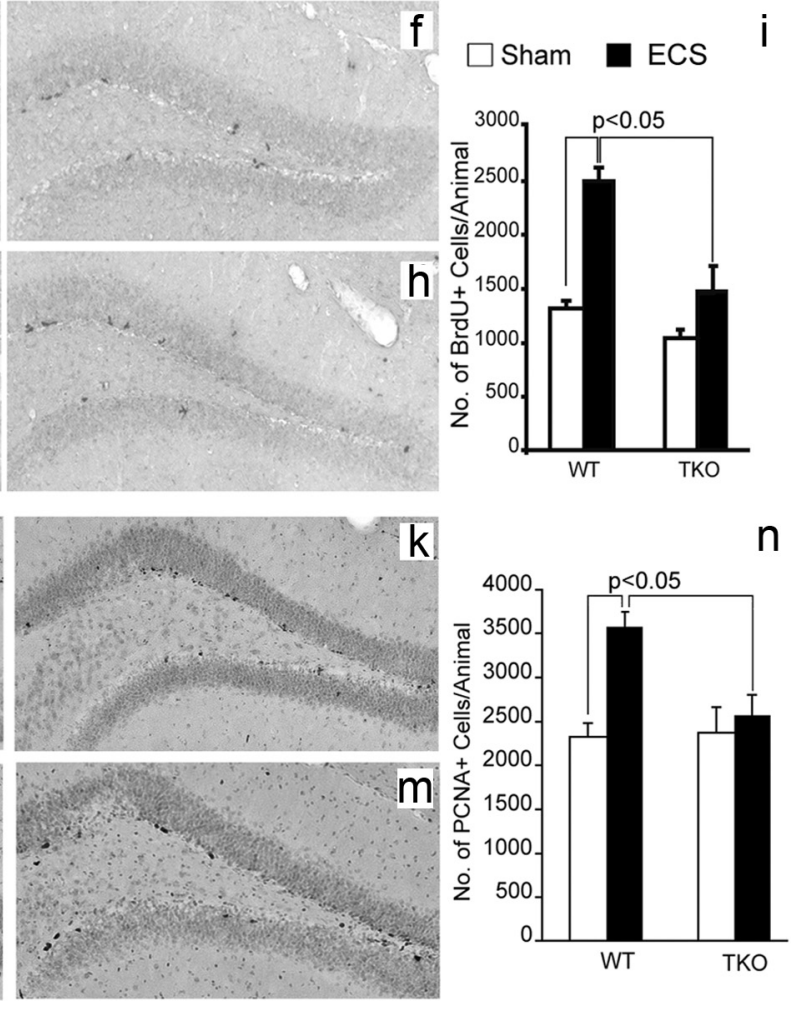

Figure 4. Tamalin deficiency blocks ECS-induced proliferation of adult hippocampal progenitors. BrdU staining of representative hippocampal sections from WT (a) and tamalin KO (b) mice showing BrdU ${ }^{+}$hippocampal progenitors in the subgranular zone (SGZ, arrowhead) of the DG, $2 \mathrm{~h}$ after BrdU injection. $\boldsymbol{c}, \boldsymbol{d}$, Quantification of BrdU ${ }^{+}$cells in the subgranular zone of the hippocampus showing no changes in basal progenitors proliferation (c) or survival (d) in WT and TKO mice. The data analyzed by Student's $t$ test represent the mean \pm SEM; $n=4-5$ per group. $\boldsymbol{e}-\boldsymbol{h}$, Representative BrdU immunohistochemistry images from sham-treated $(\boldsymbol{e}, \boldsymbol{f})$ or ECS-treated $(\boldsymbol{g}, \boldsymbol{h})$ WT $(\boldsymbol{e}, \boldsymbol{g})$ and TKO $(\boldsymbol{f}, \boldsymbol{h})$ animals. Note the mild, nonsignificant, increase of ECS-induced $\mathrm{BrdU}^{+}$proliferating progenitors in the subgranular zone of the DG of TKO mice compared with the robust increase in the WT animals $(\boldsymbol{i}) . j-m$, Representative photomicrographs of PCNA ${ }^{+}$cells as in $\boldsymbol{e}-\boldsymbol{h}$. Note the significant increase in the number of PCNA ${ }^{+}$cells only in the ECS-treated WT animals $(\boldsymbol{n})$. Data in $\boldsymbol{i}$ and $\boldsymbol{n}$ was analyzed by two-way ANOVA, followed by post hoc Bonferroni's test and represent the mean \pm SEM. $n=8-10$ per group. Two-way ANOVA revealed a significant ECS and genotype interaction for data presented in $\boldsymbol{i}\left(F_{(1,14)}=6.53, p<0.05\right)$ and $\boldsymbol{n}\left(F_{(1,32)}=5.87\right.$, $p<0.05)$.The schedules of BrdU injection and analysis for the basal proliferation $(\boldsymbol{c})$, survival $(\boldsymbol{d})$, and ECS-induced proliferation $(\boldsymbol{i}, \boldsymbol{n})$ are depicted at the top. GCL, Granular cell layer.

WT controls (data not shown; Ogawa et al., 2007). Anatomically, brains lacking tamalin do not show any gross morphological defects (data not shown). Moreover, in the elevated plus maze test, the forced swim test, and rotarod test, no abnormalities were detected, suggesting normal sensorimotor and emotional behav- ior (Fig. 3d-f). Together, these data suggest that tamalin-deficient mice do not have any overt developmental abnormalities. Next, we analyzed whether tamalin deficiency had an effect on adult hippocampal progenitor proliferation and survival. WT and TKO mice were injected with $\mathrm{BrdU}(200 \mathrm{mg} / \mathrm{kg}$, i.p) and killed $2 \mathrm{~h}$ 


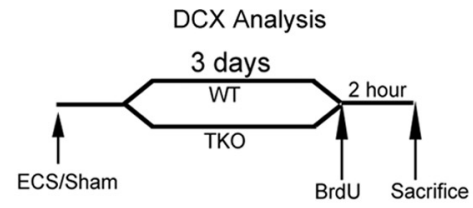

BrdU-NeuN Colocalization Analysis
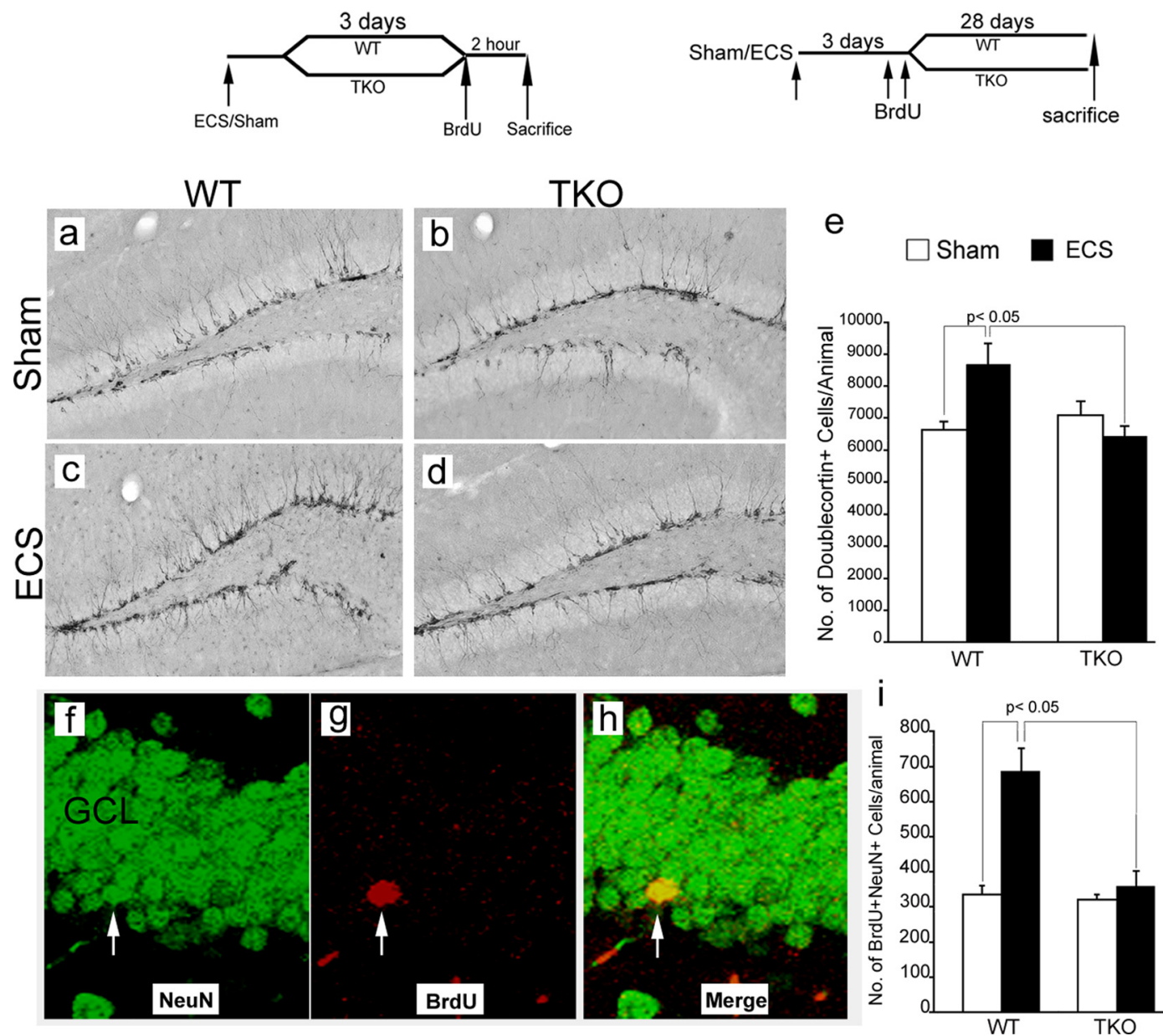

Figure 5. Tamalin is required for ECS-induced hippocampal neurogenesis. $\boldsymbol{a}-\boldsymbol{d}$, Representative immunohistochemistry images showing $D C X^{+}$(a marker for immature neurons) cells in the DG of WT $(\boldsymbol{a}, \boldsymbol{c})$ and TKO $(\boldsymbol{b}, \boldsymbol{d})$ animals subjected to sham $(\boldsymbol{a}, \boldsymbol{b})$ or ECS $(\boldsymbol{c}, \boldsymbol{d})$ treatment. $\boldsymbol{e}$, Quantitative analysis of DCX ${ }^{+}$cells showing an increase in the number of immature neurons caused by ECS in WT but not in TKO animals. $n=6-8$ animals per group. $\boldsymbol{f}$ - $\boldsymbol{h}$, Confocal $z$-stack representative images showing colocalization of BrdU ${ }^{+}$cells with NeuN, a marker for mature neurons. WT and TKO animals were subjected to a single sham or ECS treatment, and they were injected with BrdU (200 mg/kg, i.p.) $3 \mathrm{~d}$ later. $i$, Quantitative analysis showing the increase in the number of BrdU/NeuN double-positive cells caused by ECS in WT animals but not in TKO mice. $n=4-7$ animals per group. Data represent the mean \pm SEM analyzed by two-way ANOVA, followed by Bonferroni's posthoc test. Two-way ANOVA demonstrated a significant ECS $\times$ genotype interaction in both the $\operatorname{DCX}(\boldsymbol{e})\left(F_{(1,24)}=8.01, p<0.05\right)$ and $\operatorname{NeuN} / \operatorname{BrdU}(\boldsymbol{i})\left(F_{(1,19)}=8.77, p<0.05\right)$ analysis. The schedules of BrdU injection and DCX or BrdU/NeuN analysis are depicted at the top.

after BrdU for analysis of hippocampal progenitor proliferation. In agreement with a general lack of deficits in the mutant brains, we did not observe any effect in the basal proliferation and survival of adult hippocampal progenitors (Fig. $4 a-d$ ). Because ECS is known to increase hippocampal neurogenesis, we then assessed whether deletion of tamalin affects ECS-induced hippocampal progenitor proliferation (Madsen et al., 2000). Adult control and TKO mice were subjected to a single ECS and 3 d later were injected with $\operatorname{BrdU}(200 \mathrm{mg} / \mathrm{kg}$, i.p), and killed after $2 \mathrm{~h}$. Stereological analysis of $\mathrm{BrdU}^{+}$cells showed a significant $88 \%$ increase in proliferation in the hippocampus of WT animals, whereas tamalin mutant mice showed only a nonsignificant $10 \%$ increase compared with sham-treated mice (Fig. $4 e-i)$. Two-way ANOVA revealed a significant ECS and genotype interaction $\left(F_{(1,14)}=6.53, p<0.05\right)$. To further confirm the results obtained with the BrdU labeling, we performed an additional staining using the endogenous marker of cell division PCNA. After single ECS, WT animals exhibited a 54\% increase in $\mathrm{PCNA}^{+}$cells, whereas tamalin mutant mice showed only a mild, nonsignificant increase (Fig. $4 j-n$ ). Again, two-way ANOVA demonstrated a significant ECS $\times$ genotype interaction $\left(F_{(1,32)}=\right.$
5.87, $p<0.05)$. Together, these data suggest that tamalin is critical for ECS-induced, but not basal, proliferation of adult hippocampal progenitors.

\section{ECS-induced neurogenesis is blunted in TKO mice}

DG analysis with BrdU and PCNA revealed that tamalin plays a critical role in regulating ECS-induced progenitor proliferation. To investigate whether ECS-induced hippocampal neurogenesis is also affected by tamalin deletion, we stained hippocampal sections from the groups used for the BrdU and PCNA analysis with DCX, a microtubule-associated phosphoprotein used as a marker of newly born neurons in the adult DG (Rao and Shetty, 2004) (Fig. 5a-e). Stereological analysis showed a $30 \%$ increase in the number of $\mathrm{DCX}^{+}$immature neurons in ECS-treated compared with shamtreated WT animals. However, tamalin-deficient mice failed to respond to the ECS treatment because we did not detect any significant hippocampal increase in $\mathrm{DCX}^{+}$cells when compared with shamtreated WT or TKO mice (Fig. $5 a-e$ ). Because this analysis provides information only on young, immature neurons, to further investigate whether tamalin affects the ECS-induced increase of mature neurons, we subjected the animals to single ECS, followed 3 d later by 

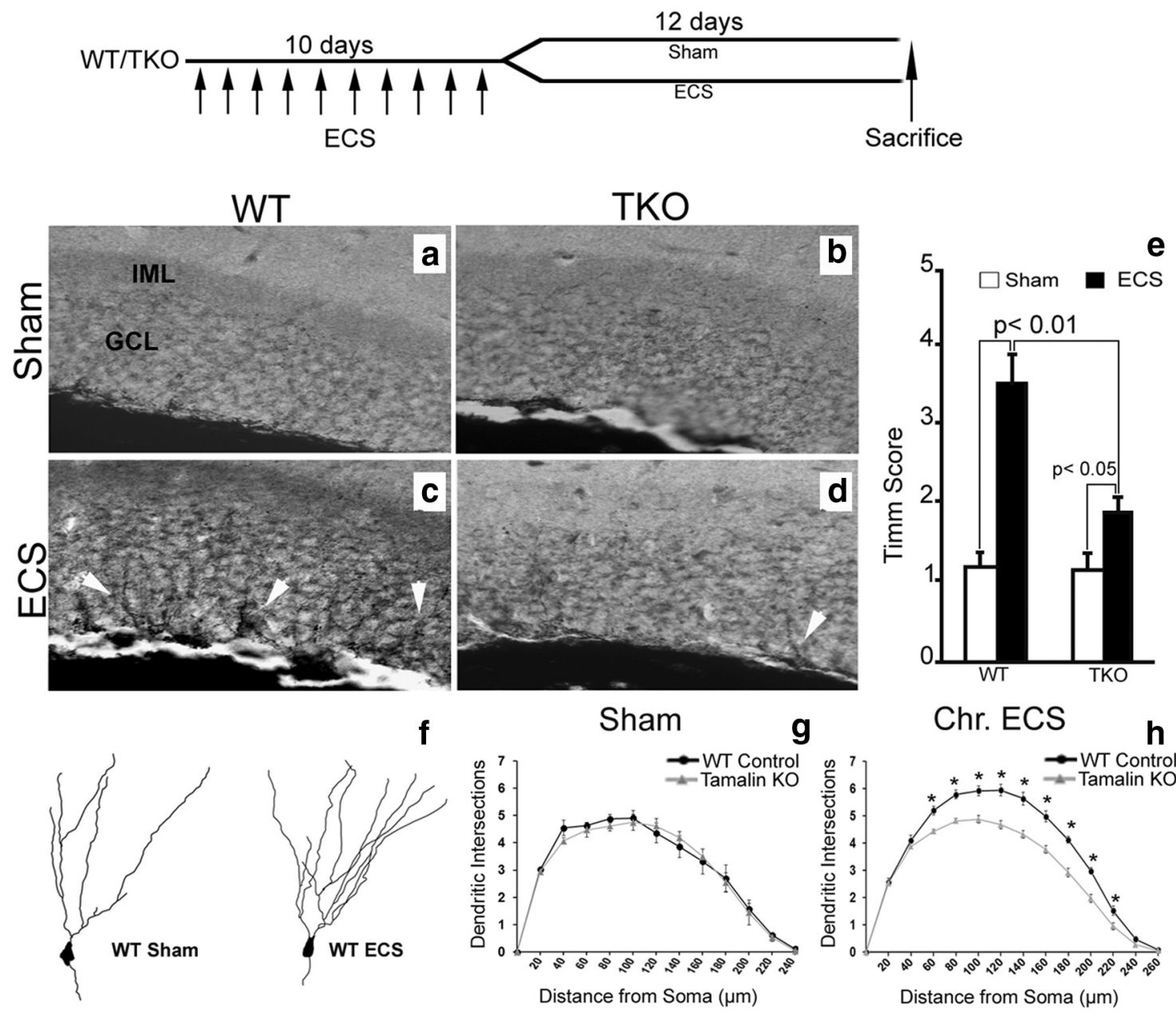

g
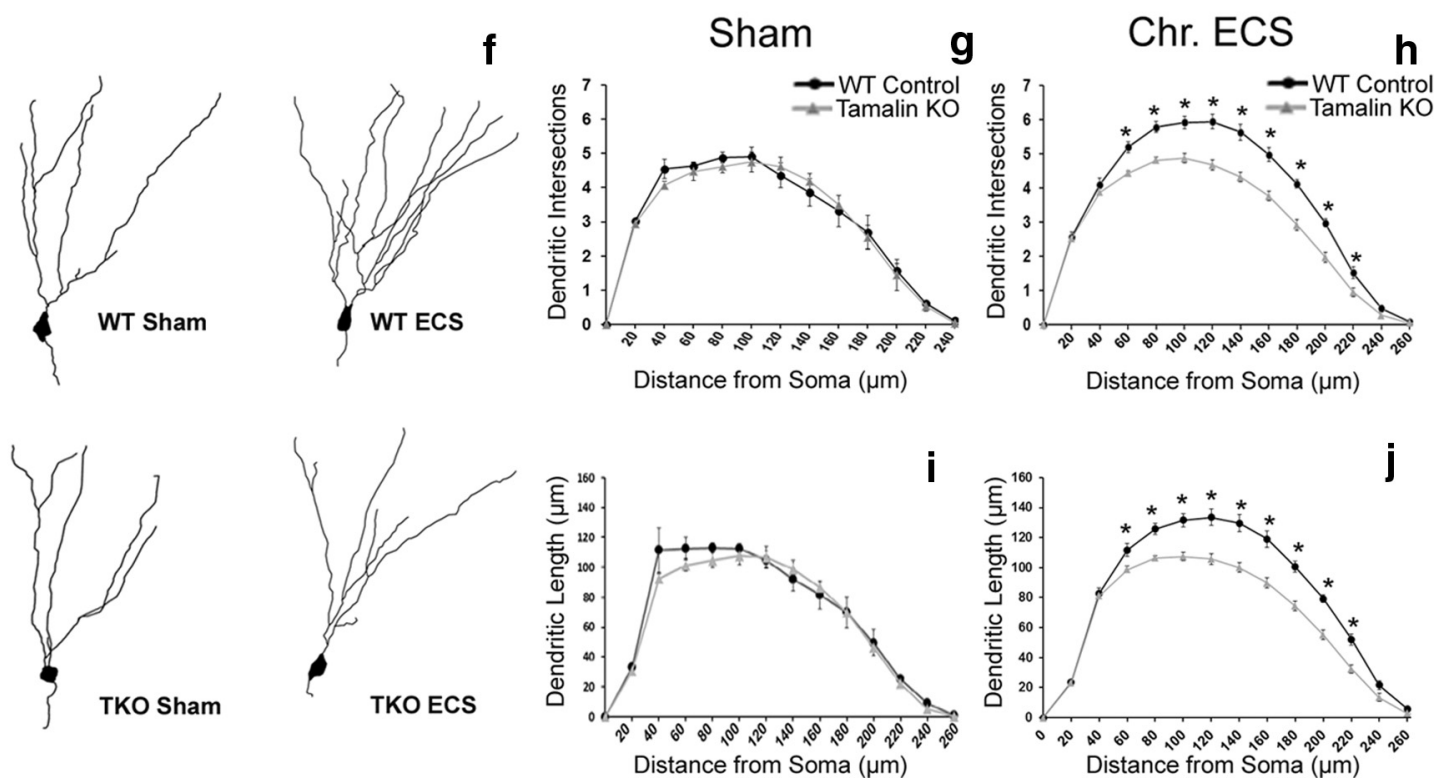

Figure 6. Chronic ECS-induced neuronal sprouting is blunted in TKO mice. Analysis of mossy fiber sprouting by Timm staining $(\boldsymbol{a}-\boldsymbol{e})$ and dendritic complexity of dentate granule cells by Golgi-Cox staining $(\boldsymbol{f}-\boldsymbol{j})$. Representative Timm-stained hippocampal sections from sham-treated $(\boldsymbol{a}, \boldsymbol{b})$ or chronic ECS-treated $(\boldsymbol{c}, \boldsymbol{d})$ WT $(\boldsymbol{a}, \boldsymbol{c})$ or TKO $(\boldsymbol{b}, \boldsymbol{d})$ mice. Note the reduced presence of Timm granules (white arrowheads in $\boldsymbol{c}, \boldsymbol{d})$ in the granular cell layer (GCL) of the hippocampus of ECS-treated TKO mice compared with ECS-treated control mice ( $\boldsymbol{n} \geq 5$ animals for each group). $\boldsymbol{e}$, Quantitative analysis of Timm scores. Data representing the mean \pm SEM was analyzed by nonparametric ANOVA, followed by post hoc Dunn test. $f$, Representative Neurolucida reconstruction of DG Golgi-stained neurons from sham-treated or chronic ECS-treated WT and TKO mice. $\boldsymbol{g}$-j, Sholl analysis of dendritic intersection number and dendrite length of DG neurons showing no difference between sham-treated WT and TKO mice $(\boldsymbol{g}-\boldsymbol{i} ; \boldsymbol{n}=5$ mice in each group; 15 neurons per mouse). Only ECS-treated WT animals display a significant increase in the number of intersections (h) and dendritic length (j) compared with sham-treated controls $(n \geq 9$ mice in each group; 15 neurons per mouse). ${ }^{*} p<0.05$. Data represent the mean \pm SEM analyzed by two-way ANOVA, followed by Bonferroni's post hoc test. Top, Schematic indicating that sham-treated or chronic ECS-treated (once per day for 10 consecutive days) animals were killed $12 \mathrm{~d}$ after the last ECS. IML, Inner molecular layer.

two BrdU injections (200 mg/kg, i.p.; $12 \mathrm{~h}$ apart) to label a pool of proliferating progenitors. Twenty-eight days after BrdU injection, which allows enough time for the maturation and differentiation of BrdU-labeled progenitors, the animals were killed, and their hippocampal sections were double stained for BrdU and the mature neuronal marker NeuN. Analysis of double-positive BrdU/NeuN cells, identified by the confocal $z$-plane sectioning method, showed that ECS-treated WT mice had approximately twice as many $\mathrm{BrdU}^{+} \mathrm{NeuN}^{+}$cells when compared with sham-treated controls (Fig. 5f-i). Sham- or ECS-treated TKO mice had a similar number of
$\mathrm{BrdU}^{+} \mathrm{NeuN}^{+}$cells as sham-treated WT controls (Fig. $5 f-i$ ). Together, these data strongly suggests that tamalin is a critical mediator of ECS-induced neurogenesis.

Tamalin is required for ECS-induced mossy fiber sprouting and granule cell dendritic arborization

In addition to increasing adult neurogenesis, ECS also causes the sprouting of dentate granule cells that is believed to contribute to the ECS therapeutic effects (Vaidya et al., 1999; Sutula, 2002). Thus, we next assessed whether tamalin is involved in the regu- 
lation of hippocampal mossy fiber sprouting after chronic ECS. Animals were subjected to ECS for 10 consecutive days (one ECS daily) and killed $12 \mathrm{~d}$ after the last treatment for mossy fiber sprouting analysis by Timm staining. Consistent with a previous report (Vaidya et al., 1999), Timm staining of brains from WT control mice subjected to chronic ECS showed a robust increase in the intensity of Timm granules in the supragranular layer of the DG. However, in TKO mice, this effect was blunted (Fig. $6 a-e$ ).

Seizure activity is known to cause an increase in the frequency of dentate granule cell basal dendrites (Spigelman et al., 1998; Ribak et al., 2000). Moreover, antidepressant treatments, including ECS or fluoxetine administration, have been shown to increase synaptogenesis, accelerate dendritic arborizations of newly generated neurons, and spine maturation of DG cells (Wang et al., 2008; Chen et al., 2009; Zhao et al., 2011). However, a direct demonstration of the effect of ECS on dendritic complexity of mature granule cells is still lacking. We therefore asked whether ECS can regulate the dendritic arborizations of mature granule cells and whether tamalin affects DG dendritic arborization in response to chronic ECS treatment. Animals were subjected to sham or chronic ECS, and DG neurons were visualized by Golgi-Cox staining, a direct method for the analysis of dendritic arborizations. Sholl analysis of neuron arborizations did not detect any difference in dendrite length or dendritic complexity between TKO or WT sham-treated animals under basal condition (Fig. $6 f-j$ ), again excluding developmental abnormalities in the mutant mice (Fig. 3). After ECS, WT mice showed increased dendrite length and dendritic intersections at $60 \mu \mathrm{m}$ and greater distances from the soma, suggesting a robust response to the treatment (Fig. $6 f-j$ ). However, TKO mice did not respond to ECS because their DG neuron arborizations were indistinguishable from those of sham-treated mice. These results further suggest that, although tamalin deletion does not affect basal neuronal morphology, it does affect neuronal sprouting after chronic ECS. Importantly, we made the novel observation that, in addition to enhancing hippocampal neurogenesis, ECS also stimulates apical dendritic arborization of DG cells, a function blunted by tamalin deletion.

\section{Tamalin affects LTP response after ECS}

Tamalin is a multimodular scaffold protein that forms a protein complex with 1/2 metabotropic glutamate receptors, guanine nucleotide exchange factor cytohesins, as well as other scaffold proteins, such as PSD-95, Mint2, and CASK, which are involved in postsynaptic organization and protein trafficking (Kitano et al., 2003). Therefore, we asked whether loss of tamalin may affect synaptic transmission in basal conditions or after ECS. We found that LTP, at $1 \mathrm{~h}$ in granule cells of the DG, induced by highfrequency stimulation of the medial perforant path was similar between WT and TKO mice, suggesting that loss of tamalin does not affect this aspect of hippocampal synaptic plasticity (Fig. 7). Furthermore, the basal synaptic transmission appeared to be normal, as assessed by the input-output curves (stimulus intensity vs
fEPSP slope; data not shown). However, after ECS, 1 h LTP was almost completely abolished in TKO mice, whereas in WT animals, it was only slightly reduced compared with animals that did not undergo ECS (not statistically significant; Fig. 7a). The input-output curve was also altered in the TKO compared with the WT mice because in the TKO it reached the maximal fEPSP amplitude earlier than in the WT (Fig. 7c). The nature of this difference is unclear and needs to be further investigated.

\section{Discussion}

In this study, we have identified tamalin as a scaffold protein that is both upregulated by ECS and required for the increased hippocampal neurogenesis and DG neuron arborizations in response to ECS. These findings establish tamalin as one of the key mediators of ECS-induced adult neuroplasticity. ECS is the most effective therapy for patients with severe depression. However, the availability of pharmacological antidepressants and the need to induce electroconvulsion in patients for ECS therapy to provide therapeutic benefit has made it an unpopular treatment choice restricting its use to treating drug-resistant or suicidal patients (Kato, 2009). This suggests that the identification of genes that are critical in the mediation of ECS effects may help dissect out the pathways that produce the positive effects of this treatment against depression without the need to induce electroconvulsion. Microarray studies have identified at least 120 genes, including transcription factors, neurotrophins, neurotransmitters, and neuropeptides, that show an altered pattern of expression after ECS (Newton et al., 2003; Altar et al., 2004). Moreover, analysis of the activity regulated transcription factor cAMP response element binding protein (CREB) has shown increased occupancy of at least 27 promoters in the hippocampus after ECS (Tanis et al., 2008). Thus, although it has been challenging to establish which of these genes are required to translate specific neurochemical changes into cellular and structural alterations, it is somewhat surprising that a single gene such as tamalin, which 
does not have obvious developmental roles, is necessary to mediate two major ECS effects (Kato, 2009). Scaffolding proteins, by means of their protein-protein interaction domains, provide a platform for regulating multiple pathways linking intracellular and extracellular events to orchestrate neuronal signaling and function. The scaffold protein tamalin interacts with group 1 and 2 metabotropic glutamate receptors, specific guanine nucleotide exchange factors, postsynaptic and protein-trafficking scaffold proteins, such as PSD95, Mint2, and CASK, as well as signaling molecules such as neurotrophin receptors and src and syk kinases (Kitano et al., 2003; Hirose et al., 2004; Esteban et al., 2006). Thus, through these complex interactions, tamalin appears to control a variety of pathways that are involved in the mediation of ECS effects. For example, neuronal progenitor proliferation may be stimulated by activating the src and syk tyrosine kinases that are expressed in the hippocampus and whose downstream signaling effectors include phospholipase C-gamma, protein kinase C, PI3kinase, ras, MAPK, and CREB (Sada et al., 2001; Hirose et al., 2004; Tian et al., 2009; Hatterer et al., 2011). Moreover, by activating the cytohesin-2-Rac1 pathway and its effectors PAKs (p21-activated kinases), tamalin may contribute to the cytoskeletal rearrangements that are essential for promoting neurite outgrowth (Bokoch, 2003; Esteban et al., 2006; Rex et al., 2007). One question that is still unresolved is how can tamalin exert these biological effects? Recently, Sugi et al. (2007), based on crystal structure and biochemical data, have proposed a model by which tamalin, at low concentrations, self-assembles into a weak-dimeric autoinhibited conformation through its PDZ domain and the C-terminal intrinsic ligand motif (Sugi et al., 2007). However, when its concentration increases, tamalin forms tetramers that in the presence of dimeric mGluR stabilize the PDZ-mediated dimerization and contribute to amplifying the assembly of signaling molecules (Sugi et al., 2007). This model appears in agreement with our findings because we have shown that ECS induces tamalin upregulation. In turn, an increase in tamalin concentration would cause the assembly of signaling molecules that are required to promote neurogenesis and neuronal sprouting in response to ECS. In this scenario, tamalin deletion is not expected to affect the expression of molecules such as mGluR5, which is indeed what we have observed in preliminary analysis (data not shown). This model would also explain why tamalin deletion does not have obvious developmental effects but can instead have such a profound effect on specific neuroplasticityassociated events. In fact, tamalin at basal, low levels would be present mainly in the inactive form, and its removal would have no major impact on development. In contrast, genes such as BDNF and VEGF, which are also required for ECS-mediated neuroplasticity, activate receptors and signaling pathways that are critical for normal developmental (Vaidya et al., 1999; Segi-Nishida et al., 2008). Therefore, although BDNF and VEGF are upstream regulators of neurogenesis and neuronal plasticity, tamalin appears to be upregulated only in response to unique situations of enhanced excitatory neurotransmission. Thus, it promotes the assembling/recruitment of the signaling pathway components that mediate only specific adult neuroplasticity-related events (Ogawa et al., 2007). In the future, it will be important to establish which tamalin-regulated pathways are contributing to the individual changes caused by ECS.

Together, our data strongly suggest that tamalin is an important mediator of ECS-induced neurogenesis and neuronal sprouting in the adult brain. Understanding which specific pathways are activated by tamalin may help provide critical targets to develop drugs that mediate the beneficial effects of ECS to treat severe depression.

\section{References}

Altar CA, Laeng P, Jurata LW, Brockman JA, Lemire A, Bullard J, Bukhman YV, Young TA, Charles V, Palfreyman MG (2004) Electroconvulsive seizures regulate gene expression of distinct neurotrophic signaling pathways. J Neurosci 24:2667-2677.

Bokoch GM (2003) Biology of the p21-activated kinases. Annu Rev Biochem 72:743-781.

Cameron HA, McKay RD (2001) Adult neurogenesis produces a large pool of new granule cells in the dentate gyrus. J Comp Neurol 435:406-417.

Carim-Todd L, Bath KG, Fulgenzi G, Yanpallewar S, Jing D, Barrick CA, Becker J, Buckley H, Dorsey SG, Lee FS, Tessarollo L (2009) Endogenous truncated TrkB.T1 receptor regulates neuronal complexity and TrkB kinase receptor function in vivo. J Neurosci 29:678-685.

Chen F, Madsen TM, Wegener G, Nyengaard JR (2009) Repeated electroconvulsive seizures increase the total number of synapses in adult male rat hippocampus. Eur Neuropsychopharmacol 19:329-338.

Esteban PF, Yoon HY, Becker J, Dorsey SG, Caprari P, Palko ME, Coppola V, Saragovi HU, Randazzo PA, Tessarollo L (2006) A kinase-deficient TrkC receptor isoform activates Arf6-Rac1 signaling through the scaffold protein tamalin. J Cell Biol 173:291-299.

Fagni L, Worley PF, Ango F (2002) Homer as both a scaffold and transduction molecule. Sci STKE 2002:re8.

Hatterer E, Benon A, Chounlamountri N, Watrin C, Angibaud J, Jouanneau E, Boudin H, Honnorat J, Pellier-Monnin V, Noraz N (2011) Syk kinase is phosphorylated in specific areas of the developing nervous system. Neurosci Res 70:172-182.

Hirose M, Kitano J, Nakajima Y, Moriyoshi K, Yanagi S, Yamamura H, Muto T, Jingami H, Nakanishi S (2004) Phosphorylation and recruitment of Syk by immunoreceptor tyrosine-based activation motif-based phosphorylation of tamalin. J Biol Chem 279:32308-32315.

Jiang X, Tian F, Du Y, Copeland NG, Jenkins NA, Tessarollo L, Wu X, Pan H, Hu XZ, Xu K, Kenney H, Egan SE, Turley H, Harris AL, Marini AM, Lipsky RH (2008) BHLHB2 controls Bdnf promoter 4 activity and neuronal excitability. J Neurosci 28:1118-1130.

Kato N (2009) Neurophysiological mechanisms of electroconvulsive therapy for depression. Neurosci Res 64:3-11.

Kitano J, Yamazaki Y, Kimura K, Masukado T, Nakajima Y, Nakanishi S (2003) Tamalin is a scaffold protein that interacts with multiple neuronal proteins in distinct modes of protein-protein association. J Biol Chem 278:14762-14768.

Ma DK, Jang MH, Guo JU, Kitabatake Y, Chang ML, Pow-Anpongkul N, Flavell RA, Lu B, Ming GL, Song H (2009) Neuronal activity-induced Gadd45b promotes epigenetic DNA demethylation and adult neurogenesis. Science 323:1074-1077.

Madsen TM, Treschow A, Bengzon J, Bolwig TG, Lindvall O, Tingström A (2000) Increased neurogenesis in a model of electroconvulsive therapy. Biol Psychiatry 47:1043-1049.

Malberg JE, Eisch AJ, Nestler EJ, Duman RS (2000) Chronic antidepressant treatment increases neurogenesis in adult rat hippocampus. J Neurosci 20:9104-9110.

Newton SS, Collier EF, Hunsberger J, Adams D, Terwilliger R, Selvanayagam E, Duman RS (2003) Gene profile of electroconvulsive seizures: induction of neurotrophic and angiogenic factors. J Neurosci 23:10841-10851.

Ogawa M, Miyakawa T, Nakamura K, Kitano J, Furushima K, Kiyonari H, Nakayama R, Nakao K, Moriyoshi K, Nakanishi S (2007) Altered sensitivities to morphine and cocaine in scaffold protein tamalin knockout mice. Proc Natl Acad Sci U S A 104:14789-14794.

Paxinos G, Franklin KB (2001) The mouse brain in stereotaxic coordinates. San Diego: Academic.

Rao MS, Shetty AK (2004) Efficacy of doublecortin as a marker to analyse the absolute number and dendritic growth of newly generated neurons in the adult dentate gyrus. Eur J Neurosci 19:234-246.

Reid SW, Tessarollo L (2009) Isolation, microinjection and transfer of mouse blastocysts. Methods Mol Biol 530:269-285.

Rex CS, Lin CY, Kramár EA, Chen LY, Gall CM, Lynch G (2007) Brainderived neurotrophic factor promotes long-term potentiation-related cytoskeletal changes in adult hippocampus. J Neurosci 27:3017-3029.

Ribak CE, Tran PH, Spigelman I, Okazaki MM, Nadler JV (2000) Status epilepticus-induced hilar basal dendrites on rodent granule cells contribute to recurrent excitatory circuitry. J Comp Neurol 428:240-253.

Sada K, Takano T, Yanagi S, Yamamura H (2001) Structure and function of Syk protein-tyrosine kinase. J Biochem 130:177-186. 
Sakagami Y, Yamamoto K, Sugiura S, Inokuchi K, Hayashi T, Kato N (2005) Essential roles of Homer-1a in homeostatic regulation of pyramidal cell excitability: a possible link to clinical benefits of electroconvulsive shock. Eur J Neurosci 21:3229-3239.

Segi-Nishida E, Warner-Schmidt JL, Duman RS (2008) Electroconvulsive seizure and VEGF increase the proliferation of neural stem-like cells in rat hippocampus. Proc Natl Acad Sci U S A 105:11352-11357.

Southon E, Tessarollo L (2009) Manipulating mouse embryonic stem cells. Methods Mol Biol 530:165-185.

Spigelman I, Yan XX, Obenaus A, Lee EY, Wasterlain CG, Ribak CE (1998) Dentate granule cells form novel basal dendrites in a rat model of temporal lobe epilepsy. Neuroscience 86:109-120.

Sugi T, Oyama T, Muto T, Nakanishi S, Morikawa K, Jingami H (2007) Crystal structures of autoinhibitory PDZ domain of Tamalin: implications for metabotropic glutamate receptor trafficking regulation. EMBO J 26:2192-2205.

Sutula T (2002) Seizure-induced axonal sprouting: assessing connections between injury, local circuits, and epileptogenesis. Epilepsy Curr 2:86-91.

Tanis KQ, Duman RS, Newton SS (2008) CREB binding and activity in brain: regional specificity and induction by electroconvulsive seizure. Biol Psychiatry 63:710-720.

Tessarollo L, Palko ME, Akagi K, Coppola V (2009) Gene targeting in mouse embryonic stem cells. Methods Mol Biol 530:141-164.

Tian HP, Huang BS, Zhao J, Hu XH, Guo J, Li LX (2009) Non-receptor tyrosine kinase $\mathrm{Src}$ is required for ischemia-stimulated neuronal cell proliferation via Raf/ERK/CREB activation in the dentate gyrus. BMC Neurosci 10:139.

Vaidya VA, Siuciak JA, Du F, Duman RS (1999) Hippocampal mossy fiber sprouting induced by chronic electroconvulsive seizures. Neuroscience $89: 157-166$
Valentine G, Chakravarty S, Sarvey J, Bramham C, Herkenham M (2000) Fragile X (fmrl) mRNA expression is differentially regulated in two adult models of activity-dependent gene expression. Brain Res Mol Brain Res 75:337-341

Wang JW, David DJ, Monckton JE, Battaglia F, Hen R (2008) Chronic fluoxetine stimulates maturation and synaptic plasticity of adult-born hippocampal granule cells. J Neurosci 28:1374-1384.

Wang Y, Mao XO, Xie L, Banwait S, Marti HH, Greenberg DA, Jin K (2007) Vascular endothelial growth factor overexpression delays neurodegeneration and prolongs survival in amyotrophic lateral sclerosis mice. J Neurosci 27:304-307.

Yanpallewar SU, Fernandes K, Marathe SV, Vadodaria KC, Jhaveri D, Rommelfanger K, Ladiwala U, Jha S, Muthig V, Hein L, Bartlett P, Weinshenker D, Vaidya VA (2010) $\alpha 2$-adrenoceptor blockade accelerates the neurogenic, neurotrophic, and behavioral effects of chronic antidepressant treatment. J Neurosci 30:1096-1109.

Zagulska-Szymczak S, Filipkowski RK, Kaczmarek L (2001) Kainateinduced genes in the hippocampus: lessons from expression patterns. Neurochem Int 38:485-501.

Zhang LL, Wang JJ, Liu Y, Lu XB, Kuang Y, Wan YH, Chen Y, Yan HM, Fei J, Wang ZG (2011) GPR26-deficient mice display increased anxiety- and depression-like behaviors accompanied by reduced phosphorylated cyclic AMP responsive element-binding protein level in central amygdala. Neuroscience 196:203-214.

Zhao C, Warner-Schmidt J, Duman R, Gage FH (2011) Electroconvulsive seizure promotes spine maturation in newborn dentate granule cells in adult rat. Dev Neurobiol. Advance online publication. Retrieved January 11, 2011. doi:10.1002/dneu.20986. 